\title{
EDITORIAL
}

\section{CORONAVIRUS, LEGISLACIÓN Y RESTRICCIONES DE DERECHOS}

Fue providencial que planeáramos que éste fuera el primer número de la Revista Chilena de Derecho que no se imprimiría, salvo para quienes lo soliciten con un sistema de print on demand (dentro de los que se incluye la Facultad de Derecho de la Universidad). Contar con una revista cuyo principal formato es el digital facilitará mucho su producción en tiempos del Covid-19, en los cuales la autoridad ha exigido cuarentenas y restricciones a eventos y reuniones de personas.

Esta pandemia ha traído bastantes novedades en el área jurídica. Por una parte, nuestro Gobierno y Poder Legislativo han propuesto y aprobado modificaciones legales para hacer frente a algunos desafíos planteados por esta enfermedad. Algunas de tales normas han contado con falencias (como la ley $\mathrm{N}^{\circ} 21.223$, que prorrogó el plazo para renovar permisos de circulación), pero otras han sido bien recibidas por los interesados. Dentro de éstas, hay muchas que interesan a la profesión jurídica, tales como la ley $\mathrm{N}^{\circ} 21.226$, que establece un régimen jurídico de excepción para los procesos, audiencias y actuaciones judiciales, y para los plazos y ejercicio de las acciones que indica, por el impacto de la enfermedad Covid-19. Estas normas, así como los autoacordados, decretos y resoluciones relevantes han sido útilmente recopiladas por el Colegio de Abogados en un compendio llamado "Normas dictadas a causa de la Covid-19"1.

Además de este tipo de normas, los abogados estaremos interesados en conocer las restricciones de derechos y libertades constitucionales, pues este coronavirus ha motivado que una o más autoridades impongan toques de queda sobre la población nacional, cuarentenas que restringen la libertad de movimiento de millones de personas, el cierre temporal de cierto tipo de negocios, entre otras medidas. A diferencia de lo que ocurrió con las órdenes que buscaban restringir ciertos derechos con posterioridad al 18 de octubre, ahora es prácticamente unánime el respaldo que ha tenido gran parte de estas medidas, a pesar de que son mucho más invasivas, y que bastantes abarcan a toda la población. Todos entendemos que ellas se decretan para obtener un bien fundamental; la preservación de la salud pública.

Sin perjuicio de lo anterior, no debemos olvidar que nuestra Constitución Política, así como los tratados vigentes en Chile, establecen límites a las restricciones que pueden imponerse a los derechos y actuaciones de las personas y demás entidades en el país. En este sentido, no cualquier autoridad puede establecer cualquier restricción, ni tampoco por cualquier medio. Por ello, los abogados debemos estar vigilantes para cuestionar los actos de las autoridades que sean contrarios a Derecho.

En esta materia, nos referiremos a un solo ejemplo. En la ciudad de Los Ángeles, el Secretario Regional Ministerial de Salud (Seremi) de la Octava Región clausuró todos los

\footnotetext{
1 Colegio de Abogados (2020): Normas dictadas a causa de la Covid-19. Actualizada al 24 de abril 2020. Disponible en: https://colegioabogados.cl/normas-dictadas-a-causa-de-la-covid-19/. Fecha de consulta: 26 de abril de 2020.
} 
templos parroquiales de dicha ciudad. Para hacerlo, se basó en la siguiente normativa: el Decreto $N^{\circ} 4$ del Ministerio de Salud, que declaró alerta sanitaria en el país y permitió que los Seremis dispongan "de las medidas necesarias para evitar aglomeraciones de gente en espacios cerrados o abiertos que puedan fomentar la propagación del virus”, y la Resolución Exenta $N^{\circ} 203$ del Ministerio de Salud, que dispuso la prohibición indefinida de eventos públicos a los que asistan más de 50 personas, y el cierre de cierto tipo de establecimientos de esparcimiento. El 23 de marzo de 2020, el Seremi de la Octava Región emitió la Resolución Exenta $N^{\circ} 1094$, donde prohibió la realización de actividades deportivas, religiosas y culturales que constituyan una aglomeración de personas, y restringió el acceso de más de 50 individuos a establecimientos comerciales.

La acción del Seremi desconoce que, a diferencia de lo que ocurre con actividades culturales y deportivas, las acciones religiosas se encuentran protegidas por el derecho humano constitucional e internacional a la libertad de religión, que incluye el ejercicio del culto. Es cierto que las acciones religiosas deben respetar la normativa de la autoridad, pero dicha regulación no puede afectar la libertad de culto en su esencia, no puede establecer mayores restricciones que las estrictamente necesarias en un Estado democrático, debe ser proporcionada y no puede establecer diferencias arbitrarias, entre otros resguardos que buscan evitar que la autoridad coarte la que ha sido llamada "la primera de las libertades".

Por su parte, las actividades religiosas en la diócesis de Santa María de Los Ángeles se estaban desarrollando según las disposiciones previas de la autoridad sanitaria, pues se cancelaron actividades extraordinarias como procesiones, y algunas ordinarias como catequesis. Además, se ordenó que determinadas personas no asistieran a misa, y que se aumentara el número de eucaristías, para que los fieles pudieran mantener la distancia dispuesta por la autoridad. Como resultado de esto, las misas se estaban celebrando con alrededor de 20 personas, las que evitaban contacto físico ${ }^{2}$. Por ello, bien podía decirse que las iglesias eran más seguras que los locales comerciales con una cincuentena de personas. En consecuencia, la prohibición de la autoridad terminó siendo un acto innecesario y desproporcionado, que afectaba mediante una simple resolución exenta un derecho humano "inderogable" según tratados internacionales fundamentales ${ }^{3}$. En definitiva, este acto administrativo padecía de inconstitucionalidad. Afortumadamente, después de varios reclamos de laicos, la autoridad dejó sin efecto su prohibición.

El Derecho nacional e internacional no exigen que el Estado sea confesional, pero sí que reconozca la dimensión religiosa del hombre. Por eso, éste no puede afrontar la presente epidemia desde una perspectiva que desconozca el hecho religioso, so pena de caer en un reduccionismo materialista, que haga sentir a los creyentes como extranjeros en su propia patria. En este sentido, también es inaceptable que el Estado permita que médicos atiendan

\footnotetext{
2 Esto se puede ver en la carta de Monseñor Felipe Bacarreza Rodríguez, disponible en PDF en: BioBiochiLE.CL (2020): "Gobierno advierte a Obispo de Los Ángeles que llamó a seguir yendo a misa: intervendría Carabineros". Disponible en: https://www.biobiochile.cl/noticias/nacional/region-del-bio-bio/2020/03/25/gobierno-advierte-aobispo-de-los-angeles-que-llamo-a-seguir-yendo-a-misa-intervendria-carabineros.shtml. Fecha de consulta: 26 de abril de 2020.

3 Art. 4, Pacto Internacional de Derechos Civiles y Políticos (1966), y Art. 27, Convención Americana sobre Derechos Humanos (1969).
} 
el cuerpo de los enfermos, pero que se impida que sacerdotes (equipados con los mismos elementos protectores que los médicos) atiendan el alma de aquellos que lo requieren, especialmente cuando los enfermos están prontos a expirar. En momentos en que gran parte de los católicos desconocen el valor de sus sacramentos, no se le puede pedir a la autoridad civil que los entienda, pero sí podemos pedir -y exigir- que respete la normativa nacional e internacional que resguarda la expresión de las creencias religiosas. Se debe reconocer la dimensión religiosa del ser humano, esa que hace que éste esté dispuesto a la muerte por preservar su relación con lo divino. Más aún, tener en consideración esta realidad puede ayudar al éxito de ciertas políticas públicas que de otro modo podrían parecer ideadas para autómatas.

Yendo ahora a cuestiones administrativas, no está de más pedir disculpas a quienes envían trabajos a la Revista Chilena de Derecho, porque estos meses ha habido un par de problemas con nuestro sistema de manejo de trabajos en línea. Por una parte, hubo algunos días en que no funcionó, producto de un hackeo que sufrió el sistema de revistas de la Universidad, lo que nos obligó a migrar inesperadamente a una nueva versión del software de manejo de trabajos. Por otro lado, encontramos varias dificultades en el proceso de cambio a este nuevo sistema. Le rogamos a nuestros lectores que tengan paciencia, pues nuestro sitio de manejo de flujos requiere de ciertos ajustes, y su apariencia necesita de algunos arreglos. Sin embargo, esta paciencia tendrá sus frutos, pues confiamos en que nuestra nueva página web sea suficientemente adecuada para permitir varios avances, por ejemplo, que a partir del próximo número publiquemos digitalmente los artículos y trabajos a medida que ellos vayan siendo aceptados, sin tener que esperar a que publiquemos la Revista como un todo.

Esperemos que nuestro próximo editorial no tenga que referirse a crisis o a epidemias. Sin embargo, si eso no llegara a ser así, consolémonos en que, como nos recuerda San Pablo, "Dios dispone todas las cosas para bien de los que lo aman..."

Álvaro Paúl D.

Director de la Revista Chilena de Derecho Pontificia Universidad Católica de Chile 